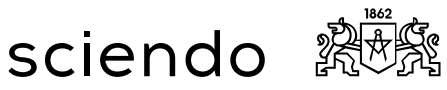 \\ RIGA TECHNICAL
}

ISSN: 2255-9671 (online)

2019, 7, 81-97

doi: 10.2478/bjreecm-2019-0005

https://content.sciendo.com

\section{INVESTIGATION OF THE ADOPTION OF BUILDING COMMISSIONING PRACTICES IN THE INSTALLATION OF BUILDING SERVICES ITEMS}

\author{
Akeem Bolaji WAHAB ${ }^{1}$, Kingsley OMAKA ${ }^{2}$ \\ ${ }^{1}$ Department of Building, Obafemi Awolowo University, Ile-Ife, Nigeria \\ ${ }^{2}$ Lagos State Ministry of Works and Housing, Alausa, Nigeria \\ Corresponding author's e-mail: wahabak2002@yahoo.com
}

\begin{abstract}
Of recent, the need to increase the performance of services installations in buildings has been a major point of interest amongst construction professionals through the consideration of commissioning practices required to be adopted during execution of building projects. The aim of the study is to investigate awareness of building professionals on the adoption of building commissioning practices in the installation and use of building services equipment. The study therefore examines the characteristics of building commissioning practices, examines the level of awareness and adoption of building commissioning practices amongst construction professionals in Lagos State, Nigeria, as well as investigates the factors influencing their adoption. A survey method of research was employed with questionnaire administered on construction professionals available on the list of firms of the Federation of Construction Industry (FOCI) registered with the Lagos State Government. The data collected were analysed with the use of statistical tools, such as frequency distribution, mean item score, analysis of variance and factor analysis. The study shows that amongst the characteristics of building commissioning practices, lighting services have the highest level of engagement with a mean score of 4.45, heating, ventilation and air-conditioning 4.15 while vertical transporting services have a mean score of 3.82. A significant proportion of the respondents are aware of building commissioning practices through different professional training courses and practices. The study also shows that there is relationship between the level of awareness and adoption of building commissioning practices at $95 \%$ confidence level. The indicators in group one are found through the factor analysis to be contributing mostly to the adoption of building commissioning practices by the respondents. The study concludes that with the existing level of its awareness in the study area, efforts should be made by stakeholders to entrench building commissioning practices provisions in the country's institutional framework/regulatory code, which covers the installation and use of service items in building stock so as to further deepen their adoption in order to enhance performance and comfort of building projects.
\end{abstract}

Keywords: buildings, commissioning, items, performance, practices, services. 


\section{INTRODUCTION}

In recent times, most new buildings have been built with highly complex and complicated heating, ventilating and air conditioning (HVAC) systems that depend on electronic control systems (Altwies, 2002). However, in many of such buildings, most of these systems and design features have not been executed in the projects as expected. This has resulted in increased liability for building owners, operators, employers as well as design professionals. It has also increased energy efficiency losses, residents' agitations about poor indoor air quality and lastly, has led to an increase in operating cost (D'Antonio, 2007).

A building is formed from the combination and integration of several building elements and components as well as different systems, which include heating, ventilation and air conditioning (HVAC) system, lighting system, transportation system amongst others (ASHRAE, 2005). Heating, ventilation and air conditioning system plays crucial roles in the performance and use of buildings. It helps in replacing air in any building space so as to provide good indoor air quality, and this entails a lot of things, such as periodic temperature checks, oxygen refill into the space and removal of smoke, heat and dust from the building space. This means that if the HVAC system in a building is not performing optimally, it may cause a number of problems ranging from persistent complaints from the building occupants to vacation of the building spaces by the habitants when they feel they can no longer tolerate the discomfort they experience from the use of such buildings (DOE, 2007). This then requires interventionist approaches in order to optimize functions of building systems.

A building is made up of the systems mentioned above and others, which are co-integrated together and work simultaneously to give a major single goal that is to give maximum satisfaction and comfort to the building occupants through emerging concepts such as building commissioning. Building commissioning process ensures a continuous and effective performance of all the systems and components that make up a building. Building commissioning is a planned, ordered, procedural and documented process of ensuring that building owners' needs are met, building systems perform optimally and building operators are well trained (Mantai, 2006). Building commissioning ensures that all structural and mechanical systems are properly installed, functionally tested and are in alliance with the design purpose. In other words, building commissioning comprises thorough checking and ratifying building systems to verify various aspects of building design, making sure that the building is constructed based on the contract documents, and also verifying that the building and its systems function as intended. It also helps integrate and organise the design, construction, operations and maintenance of all components and systems that form the buildings (Maisley and Milestone, 2006).

The construction industry provides the lion share of so many nations' economies. The reason being that between $30 \%-40 \%$ of the natural resources are used in the construction industry and about $50 \%$ of the energy used worldwide is used for heating and cooling the buildings (Bourdeau, 1999). Nigeria as a country is not left out of these statistics. Owning and operating a building requires a substantial financial investment. Poor building performance means that building 
owners may lose money. Excessive repairs, replacement and poor indoor air quality cost building owners a lot of money. In fact, the question of how to reduce energy losses, excessive repairs and replacement, as well as provision of adequate indoor air quality in buildings, not only for the generation we are in now, but also for the unborn generation, has brought about the emergence of building commissioning (Tseng, 2005). Consequently, building commissioning practices have emerged to correct the inadequacies of conventional building operations and they are involved in the design, construction, post construction and post-occupancy phase, respectively.

Nigeria as a country is in dispensation when there is a need to reduce the amount of energy lost in buildings, to improve indoor air quality of building spaces, to reduce the cost of running buildings, to mitigate the risk and liabilities of building owners, employers and design experts (D'Antonio, 2007). It is believed that any information provided in this regard will contribute to the volume of knowledge in the Nigerian construction industry and give building professionals more insight into the benefits of building commissioning practices. Thus, the aim of the study is therefore to investigate the adoption of building commissioning practices in the installation and use of building services equipment with a view to assessing the level of their awareness while its specific objectives are to examine the characteristics of building commissioning practices; to examine the level of awareness and adoption of building commissioning practices amongst professionals in the construction industry; and to examine the factors influencing the level of awareness and adoption of building commissioning practices in the study area.

\section{Literature Review on History of Building Commissioning Practices}

Building systems place emphasis on the evaluation, selection and integration of mechanical, electrical and other specific systems in building design and construction. Building systems comprise, mechanical, electrical, plumbing, sanitary, heating, ventilation and air conditioning, security, life safety, building management, transport and all other services, systems or facilities located in buildings" (Judelson, 2007). Building systems can also be seen as the critical systems of one's facility such as the electrical, heating, ventilation and air conditioning systems, security, life safety, lightning, telecoms and energy management systems. These systems are rarely, if ever, independent entities, as they are mutually dependent in order to enhance building operations during its life cycle, provide comfort and communications to the users of the building and are really essential for good building design. Building systems especially heating and cooling systems are responsible for a high proportion of building operating costs. This lays importance on approaches to entrench their effective usage (Shoop, 2005).

Building commissioning is not very different from the commissioning that is found in the Navy. Commissioning was firstly introduced into the construction industry in the late 1970s. The main reason why commissioning emerged was a response to the energy crisis that affected sustainability. At that time, many designers utilised sophisticated equipment that needed continuous maintenance, which in turn, required commissioning. In 1997, the Public Works of Canada was 
the first organisation to use building commissioning in the delivery of building projects. Later, in 1981, Disney used building commissioning during the design, construction, and start-up of Epcot projects. Then, in 1984, the American Society of Heating, Refrigerating, and Air-Conditioning Engineers (ASHRAE) instituted the Commissioning Guideline Committee. The term of reference of the committee was to define a process which ensures that only fully functional buildings would be handed over to the owners (ASHRAE, 2005). The driving force for ASHRAE commissioning committee was the growing number of complaints about several unmanageable HVAC systems, increasing operation expenses, decreasing comfort levels, uneducated operations and maintenance personnel who were not knowledgeable on how to run complex building systems (ASHRAE, 2005). After these events, different governmental and private organisations started to take interest in building commissioning. In 1993, the first national conference on building commissioning was held in the United States and in 1996, the building commissioning association was established to help regulate and connect building commissioning industry (Turkaslan-Bulbul, 2006). Finally, in 2000, the United States Green Building Council (USGBC) required that commissioning should be part of its Leadership in Energy and Environmental Design (LEED) requirements so as to improve performance of building stock. This has served as the major green light for the intervention to be in public domain (Energy, 2005).

\section{Definition of Building Commissioning}

According to NEBB (2019), building commissioning is the process of verifying subsystems of the mechanical, plumbing, electrical, fire/life safety, building envelopes, interior systems, co-generation, utility plants, sustainable systems, lighting, wastewater, controls, and building security in order to achieve requirements intended by the building owner and as may designed by the building professionals". Building commissioning can also be seen as "the systematic process of ensuring that a building's complex array of energy-related systems is designed, installed and tested to perform according to the design intent and building owners' operational needs" (Energy, 2005). In the actual sense, building commissioning process is needed to ensure that a new building sustains its life cycle at an optimal level through low-cost and low-risk management strategy, which extends beyond operational efficiencies and cost savings to improve occupants' comfort, productivity, indoor air quality and to reduce maintenance and operating expenses with the attainment of extended service life of the equipment (Dorsett, 2008; Evans, 2011). As observed, the practice of building commissioning process is quickly gaining recognition in the construction industry; it is now becoming a norm that building owners and developers would try to get more out of their investment. Usually, the main goal of the commissioning process is to improve a project from the design phase through the post construction and occupancy stages that it would transit" (EPA, 2001). 


\section{Benefits of Building Commissioning}

Usually, a number of different benefits can be obtained from a well-commissioned building. These benefits may vary from optimised energyefficient design features to the occurrence of reduced indoor air quality. According to DOE (2007), "the building owner is best positioned to have his facility to function adequately and in line with its design intent". It can also result in savings because operating cost for commissioned buildings is $8 \%-20 \%$ less than the cost of operating a non-commissioned building and also serves as opportunities to reduce energy costs and greenhouse gas emissions (Engineered, 2005; Raymond, 2010; Mills, 2011). Reduced operation and maintenance costs together with the likely savings from reduced energy costs would be of benefit to the owner. Aside from financial savings, there are other benefits accruable from commissioning a building. According to DOE (2007), other types of benefits include reduced quantity of change orders as it would foster better communication between project team members and early detection of potential problems, savings in energy cost through improved building systems performance and preventive maintenance. It also verifies that the owner-intended design features could be properly installed into the facility, and the early detection of potential problems would result in less expensive repairs.

\section{Building Commissioning Types and Characteristics}

In the available literature, there are different types of commissioning processes that building stock can undergo and they consist of continuous commissioning, retro-commissioning and re-commissioning. According to Dorsett (2008), continuous commissioning involves the art of commissioning of new buildings in which there would be allocation for increasing commissioning throughout life cycle of the building. Commissioning ensures that a new building operates as the owner intended and the building staff are prepared to operate and maintain its system and equipment" (Peter, 2015; NIS, 2016), but, on the other hand, retro-commissioning, is a process that helps improve the way building equipment and systems operate and function together. Depending on the age of the building, retro-commissioning can often address problems that occurred during the design or construction, or solve problems that have occurred throughout the building life" (Energy, 2005); re-commissioning occurs when a building that has already been commissioned undergoes another commissioning process. It is one of the steps that can be taken to ensure that retro-commissioning and other efficiency measures last and to ensure the sustainability of the associated benefits (Peter, 2015; Johnson, 2018).

Generally, in view of the different types of building commissioning processes, the commonly available characteristics are as follows: provision of adequate amount of lighting, improved energy conservation through the use of energy saving bulbs, reduced quantity of heat released into building space, provision of good indoor air quality, improved energy conservation through the use of energy efficient HVAC, reduced maintenance costs due to improved reliability and extended life expectancy of the HVAC system, reduced energy use of systems through the use of 
energy efficient systems and enhanced comfort of the occupants through the use of reliable brands of systems to be installed in the buildings (Energy, 2005).

\section{RESEARCH METHODOLOGY}

The study was carried out in Lagos State, Nigeria, to investigate the adoption of building commissioning practices by professionals in the construction industry, to examine the characteristics of building commissioning practices and to investigate the factors influencing the level of awareness and adoption of building commissioning practices in the study area. Target population usually spells out the group of people that a researcher would want to draw conclusion from when the research is completed (Korb, 2012). The process of identifying target population requires specifying the criteria that determine which individuals are not included. It also explains the importance of specifying the general, target and accessible population in a qualitative study when the study population is large (Korb, 2012; Asiamah, Mensah and Oteng-Abaye, 2017). The target population in this study consisted of registered construction firms and consultants in Lagos State, Nigeria. These are the construction firms who either have their head offices in Lagos or have their branch offices there or are currently engaged in construction projects in Lagos. The consultant group was made up of architects, builders, facility managers and building services (mechanical and electrical) engineers.

According to Levy and Lemeshow (2009), sampling is "the process of choosing the number of observations to be included in a statistical sample". The sample size is an important feature of any empirical study in which the goal is usually to draw inferences about a population under consideration. If a sample is not a true representation of the target population, it may lead to unreliable conclusion (Sarmah and Hazarika, 2012). In statistics, a sampling frame is the source material or device from which a sample is drawn and shows the complete list of the sample units that can potentially be selected in the population (Schreuder, Ernst and RamirezMaldonado, 2004). Sampling is generally conducted to permit the detailed study of the part, as against whole of the population (Kenneth, 2005). The information on the registered construction firms as obtained from the Federation of Construction Industry (FOCI) official website as of July, 2016 showed that only 78 construction firms were registered members of the FOCI. However, it was identified that at least fifty-three (53) out of the seventy-eight (78) construction firms available on the membership list either had their head offices or branch offices situated in Lagos State. From the preliminary survey carried out, the sampling frame available for sampling in Lagos State on the FOCI list included the 53 construction firms. Furthermore, a sample of consultants engaged in projects handled by the construction firms was also considered.

From the given population of contractors in this study, total enumeration of the fifty-three (53) construction firms registered with FOCI (www.foci.org.ng) was used. Thus, the sample size for the contractors consisted of 53 construction firms in Lagos State. Due to the information obtained during the preliminary survey, purposive sampling was used to identify and select two (2) of the contractors' personnel that possessed sufficient experience to provide the required information 
on the subject matter. This informed the selection of one hundred and six personnel working in the construction firms sampled. Thus, a total of 106 copies of the questionnaire were administered on the contractors' personnel in the study area. Furthermore, a snowballing approach was used to select the consultant population. This was done by identifying the consultants that were involved in the projects executed by the selected contractors. These included architects, builders, facility managers, and building services engineers (mechanical and electrical). This is because the architects are usually involved in the project from the inception and also act as the client's representative in most projects. Through a snowballing approach, a total of seventy-four (74) copies of questionnaire were administered on the consultants. Hence, a total of one hundred and eighty (180) copies of questionnaire were administered on all the respondents selected during the course of the study, which comprised 106 personnel of the construction firms and 74 consultants. The data collected were analysed with the use of descriptive and inferential statistical methods such as frequency distribution, mean item score, analysis of variance and factor analysis.

\section{RESULTS AND DISCUSSION}

The results of the study showed that out of the total of one hundred and eighty questionnaires that were administered on the respondents, one hundred and fifty were retrieved and this indicated a response rate of $83.33 \%$. Majority of the respondents sampled $(50.7 \%)$ had bachelor's degree in their various areas of disciplines, $88.7 \%$ had between 5-10 years of work experience, while $6.7 \%$ had 11-15 years of involvement in the building industry. This ought to give them reasonable background on the scope of building commissioning practice in view of the nature of building projects that they have been involved in. The examination of the various characteristics of building commissioning practices, which involve three categories, namely, lighting, heating, ventilation and air conditioning (HVAC) and vertical transportation system as extracted from the body of literature with their respective variables are coded and shown in Table 1.

Table 1. Dimensioning of Building Commissioning Practices (developed by the authors)

\begin{tabular}{|l|l|l|c|}
\hline $\begin{array}{l}\text { Item } \\
\text { Code }\end{array}$ & Characteristics & Variable Measured & $\begin{array}{c}\text { Dimension } \\
\text { Number }\end{array}$ \\
\hline P1 & Lighting & $\begin{array}{l}\text { Provision of adequate amount of lighting which is } \\
\text { needed in different parts of the building }\end{array}$ & \\
\hline P2 & Lighting & $\begin{array}{l}\text { Improved energy conservation through the use of } \\
\text { energy saving bulbs }\end{array}$ & 1 \\
\hline P3 & Lighting & $\begin{array}{l}\text { Reduced amount of heat released into the building } \\
\text { space through the use of energy saving bulbs }\end{array}$ & \\
\hline P4 & HVAC & Provision of good indoor air quality & \\
\hline P5 & HVAC & $\begin{array}{l}\text { Improved energy conservation through the use of } \\
\text { energy efficient HVAC }\end{array}$ & 2 \\
\hline
\end{tabular}




\begin{tabular}{|l|l|l|c|}
\hline $\begin{array}{l}\text { Item } \\
\text { Code }\end{array}$ & Characteristics & Variable Measured & $\begin{array}{c}\text { Dimension } \\
\text { Number }\end{array}$ \\
\hline P6 & HVAC & $\begin{array}{l}\text { Lower maintenance cost due to enhanced reliability } \\
\text { and longer life expectancy of HVAC system }\end{array}$ & \\
\hline P7 & $\begin{array}{l}\text { Vertical } \\
\text { transportation } \\
\text { system }\end{array}$ & $\begin{array}{l}\text { Lower maintenance cost due to enhanced reliability } \\
\text { and longer life expectancy }\end{array}$ & \\
\hline P8 & $\begin{array}{l}\text { Vertical } \\
\text { system }\end{array}$ & $\begin{array}{l}\text { Reduced energy use of system through the use of } \\
\text { energy efficient systems }\end{array}$ & \\
\hline P9 & $\begin{array}{l}\text { transportation } \\
\text { system }\end{array}$ & $\begin{array}{l}\text { Reduced travel time and increased comfort of } \\
\text { occupants through the use of trusted and tested } \\
\text { brands }\end{array}$ & \\
\hline
\end{tabular}

Table 2 shows the mean score values of various characteristics of building commissioning practices as any score with a mean value of 3.0 is perceived to be popularly accepted as significant by majority of the respondents. Thus, the assessment of the mean value of each of the characteristics was considered in this study (lighting 4.45, HVAC 4.15 and vertical transportation system 3.82). This indicated that majority of the respondents were significantly involved in the stock of building projects that involved the incorporation of lighting features, followed by the incorporation of the heating, ventilation and air conditioning components and inclusion of vertical transportation system being the least service provided.

Table 2. Characteristics of Building Commissioning Practice (developed by the authors)

\begin{tabular}{|c|c|c|c|c|c|c|}
\hline & $\begin{array}{c}\text { Most } \\
\text { significant } \\
(\%)\end{array}$ & $\begin{array}{c}\text { Highly } \\
\text { significant } \\
(\%)\end{array}$ & $\begin{array}{c}\text { Significant } \\
(\%)\end{array}$ & $\begin{array}{c}\text { Fairly } \\
\text { significant } \\
(\%)\end{array}$ & $\begin{array}{c}\text { Least } \\
\text { significant } \\
(\%)\end{array}$ & $\begin{array}{c}\text { Mean } \\
\text { Score }\end{array}$ \\
\hline & \multicolumn{7}{|c|}{ Lighting } \\
\hline P1 & $51(34.00)$ & $91(60.67)$ & $5(3.33)$ & $3(2.00)$ & $0(0.00)$ & 4.48 \\
\hline P2 & $31(20.67)$ & $88(58.66)$ & $21(14.00)$ & $12(8.00)$ & $0(0.00)$ & 4.42 \\
\hline P3 & $43(28.67)$ & $88(58.66)$ & $15(10.00)$ & $3(2.00)$ & $1(0.67)$ & 4.46 \\
\hline \multicolumn{7}{|c|}{ HVAC } \\
\hline P4 & $41(27.33)$ & $53(35.33)$ & $48(32.00)$ & $7(4.67)$ & $1(0.67)$ & 4.15 \\
\hline P5 & $23(15.33)$ & $61(40.67)$ & $51(34.00)$ & $10(6.67)$ & $5(3.30)$ & 4.32 \\
\hline P6 & $39(26.00)$ & $40(26.67)$ & $37(24.67)$ & $19(12.67)$ & $15(10.00)$ & 3.92 \\
\hline & \multicolumn{7}{|c|}{ Vertical Transportation System } & 3.82 \\
\hline P7 & $18(12.00)$ & $36(24.00)$ & $75(50.00)$ & $19(12.67)$ & $2(1.30)$ & 3.79 \\
\hline P8 & $42(28.00)$ & $70(46.67)$ & $29(19.33)$ & $9(6.00)$ & $0(0.00)$ & 4.11 \\
\hline P9 & $24(16.00)$ & $42(28.00)$ & $36(24.00)$ & $36(24.00)$ & $12(8.00)$ & 3.56 \\
\hline
\end{tabular}

The level of awareness and adoption of building commissioning practices is described further. 


\section{Level of Awareness and Adoption of Building Commissioning Practices}

Table 3 shows the frequency distribution of respondents' level of awareness and adoption of building commissioning practices. Most of the respondents, precisely $92.7 \%$, reported to have heard about building commissioning and this showed an appreciable level of awareness. About $52(37.4 \%)$ reported to have heard about building commissioning through their professional practices, $27(19.4 \%)$ from professional workshops, $13(9.4 \%)$ from academic workshops, $26(18.7 \%)$ from the internet, $18(12.9 \%)$ from textbook and only $3(2.2 \%)$ claimed to have their source of awareness from the newspapers. Table 3 also shows an adoption rate of $79.3 \%$ as 119 respondents reported that their projects were currently being commissioned, while $114(76 \%)$ respondents reported that there was trend towards commissioning of building projects. Equally, Table 4 indicates the level of awareness of respondents of building commissioning in Lagos State. From the mean score of each of the indicators measuring awareness that is above 3.0 , it can be concluded that most of the respondents are appreciably aware of building commissioning in the study area. The information on the frequency distribution of respondents' level of awareness and adoption of building commissioning practices is shown at Table 3.

Table 3. Frequency Distribution of Respondents' Level of Awareness and Adoption of Building Commissioning Practices (developed by the authors)

\begin{tabular}{|c|c|c|}
\hline $\begin{array}{c}\text { Have you ever come across } \\
\text { the term called building } \\
\text { commissioning? }\end{array}$ & Frequency & Percentage \\
\hline Yes & 139 & 92.70 \\
\hline No & 11 & 7.30 \\
\hline Total & 150 & 100.00 \\
\hline \multicolumn{3}{|c|}{ Source of awareness } \\
\hline Professional practice & 52 & 37.40 \\
\hline Professional workshops & 27 & 19.40 \\
\hline Academic workshops & 13 & 9.40 \\
\hline Internet & 26 & 18.70 \\
\hline Newspapers & 3 & 2.20 \\
\hline Textbooks & 18 & 12.90 \\
\hline Total & 139 & 79.30 \\
\hline \multicolumn{2}{|c|}{ Are any of your projects currently being commissioned? } \\
\hline Yes & 119 & 20.70 \\
\hline No & 31 & 100.00 \\
\hline Total & 150 & 4.60 \\
\hline What approximate percentage of your projects involve building commissioning? \\
\hline \% & 7 & 6.00 \\
\hline $1-25$ & 9 & 38.70 \\
\hline 2645 & 76 & \\
\hline 4665 & 58 & \\
\hline 66 and above & \multicolumn{2}{|c|}{} \\
\hline \multicolumn{2}{|c|}{} &
\end{tabular}




\begin{tabular}{|c|c|c|}
\hline Total & 150 & 100.00 \\
\hline Do you think there is a trend towards commissioning of building projects in Lagos state? \\
\hline Yes & 114 & 76.00 \\
\hline No & 36 & 24.00 \\
\hline Total & 150 & 100.00 \\
\hline
\end{tabular}

The level of awareness and adoption of building commissioning practices is shown at Table 4.

Table 4. Level of Awareness and Adoption of Building Commissioning Practices (developed by the authors)

\begin{tabular}{|c|c|c|c|c|c|c|}
\hline Responses & $\mathbf{1}$ & $\mathbf{2}$ & $\mathbf{3}$ & $\mathbf{4}$ & $\mathbf{5}$ & Mean Score \\
\hline $\begin{array}{c}\text { To what extent is your level of personal } \\
\text { knowledge of the commissioning process? }\end{array}$ & 0 & 2 & 21 & 77 & 50 & 4.23 \\
\hline $\begin{array}{c}\text { To what extent is your company's level of } \\
\text { knowledge of the commissioning process? }\end{array}$ & 0 & 0 & 12 & 76 & 62 & 4.37 \\
\hline $\begin{array}{c}\text { What is your company's level of reliance on sub- } \\
\text { contractors' roles in the commissioning process? }\end{array}$ & 1 & 3 & 24 & 64 & 58 & 4.18 \\
\hline $\begin{array}{c}\text { To what extent is your company's level of } \\
\text { reliance on the mechanical and electrical } \\
\text { engineers involved in the building commissioning } \\
\text { process? }\end{array}$ & 2 & 3 & 19 & 60 & 66 & 4.02 \\
\hline $\begin{array}{c}\text { How beneficial do you feel the commissioning } \\
\text { process helps meet the owner's expectations? }\end{array}$ & 1 & 2 & 11 & 66 & 70 & 4.40 \\
\hline $\begin{array}{c}\text { How effective do you feel that commissioning } \\
\text { helps reduce the number of call-backs after a } \\
\text { project is completed? }\end{array}$ & 5 & 9 & 16 & 76 & 44 & 3.92 \\
\hline $\begin{array}{c}\text { To what extent do you think building } \\
\text { commissioning helps achieve cost-saving } \\
\text { measures? }\end{array}$ & 4 & 3 & 13 & 84 & 46 & 4.01 \\
\hline $\begin{array}{c}\text { How effective do you feel that a third-party } \\
\text { commissioning agent is in terms of streamlining } \\
\text { the commissioning process? }\end{array}$ & 6 & 11 & 51 & 58 & 24 & 3.87 \\
\hline
\end{tabular}

The relationship between the level of awareness of building commissioning practices and their adoption in projects in the study area is shown in Table 5. Table 5 indicates through the chi-square analysis that at the probability value of 0.00 , there was a significant relationship between the two variables at $95 \%$ confidence level. Chi-Square analysis of the relationship between the level of awareness of building commissioning practice and its adoption is shown at Table 5. 
Table 5. Chi-Square Analysis of the Relationship between the Level of Awareness of Building Commissioning Practice and Its Adoption (developed by the authors)

\begin{tabular}{|c|c|c|c|c|c|}
\hline & Value & Df & $\begin{array}{c}\text { Asymp. Sig. } \\
\text { (2-sided) }\end{array}$ & $\begin{array}{l}\text { Exact. Sig. } \\
\text { (2-sided) }\end{array}$ & $\begin{array}{l}\text { Exact. Sig. } \\
\text { (1-sided) }\end{array}$ \\
\hline Pearson Chi-Square & $18.927^{\mathrm{a}}$ & 1 & 0.000 & & \\
\hline Continuity Correction $^{\mathrm{b}}$ & 16.631 & 1 & 0.000 & & \\
\hline Likelihood Ratio & 19.206 & 1 & 0.000 & & \\
\hline Fisher's Exact Test & & & & 0.000 & 0.000 \\
\hline $\begin{array}{l}\text { Linear-by-Linear } \\
\text { Association }\end{array}$ & 18.806 & 1 & 0.000 & & \\
\hline No of Valid Cases & 157 & & & & \\
\hline
\end{tabular}

Factors influencing the adoption of building commissioning practices can be found in the next subpart.

\section{Factors Influencing the Adoption of Building Commissioning Practices}

From the literature reviewed, there are several factors that can influence the adoption of building commissioning practices by the respondents. For the purpose of this study, twenty factors were identified and were assessed through the use of factor analysis through their natural groupings so as to identify each of the variables and to determine the groups that the variable would fall into through their factor loadings. Preliminarily, the Kaiser-Meyer-Olkin (KMO) and Bartlett's tests were carried out on the data obtained to determine the adequacy of the data for factor analysis and its result as presented in Table 6 . Table 6 shows that in respect of the justification of factor analysis, a KMO value of 0.695 is a value higher than the minimum of 0.600 according to Kaiser (1974). KMO and Bartlett's test on the factors influencing adoption of building commissioning practices are shown at Table 6.

Table 6. KMO and Bartlett's Test on the Factors Influencing Adoption of Building Commissioning Practices (developed by the authors)

\begin{tabular}{|l|l|l|}
\hline KMO and Bartlett's Test & 0.695 \\
\hline Kaiser-Meyer-Olkin Measure of Sampling Adequacy & 491.218 \\
\hline \multirow{3}{*}{ Bartlett's Test of Sphericity } & Approx. Chi-Square & 136 \\
\cline { 2 - 3 } & Df & 0.000 \\
\cline { 2 - 3 } & Sig. & \\
\hline
\end{tabular}

Thus, to optimise the factor structure and search for the best explanation of patterns in the data, factor rotation (Varimax with Kaiser Normalization) was applied. Each of the items that loaded up to 0.50 (bold values above) were grouped under the 5 identified components or groups of factors. These factors could be stated to have a significant effect on the dependent variable; level of awareness and adoption of building commissioning practices as shown in Table 7 . The groups are as stated in the bold forms: 
Group 1: Level of awareness, Level of demand for building commissioning practices, Rate of financial return from the adoption of building commissioning practices, Level of technology involved, Scope of building materials and applications needed, and Phases of renovation involved in a building project.

Group 2: Size and complexity of building, Nature of equipment to be installed, and Reliability and performance level of the installed building components.

Group 3: Scope of heating, ventilating, and air conditioning (HVAC) component needed, and Proficiency of design and construction professionals.

Group 4: Level of demand for elaborate building systems, and Fees paid for the team of professionals on the project.

Group 5: Level of sophistication and functional testing during start-up, and Environmental risk assessment of building system.

Rotated component matrix on the factors influencing adoption of building commissioning practices is shown at Table 7 .

Table 7. Rotated Component Matrix on the Factors Influencing Adoption of Building Commissioning Practices (developed by the authors)

\begin{tabular}{|c|c|c|c|c|c|}
\hline & \multicolumn{5}{|c|}{ Component } \\
\hline & 1 & 2 & 3 & 4 & 5 \\
\hline Size and complexity of building & 0.345 & 0.768 & -0.059 & 0.046 & 0.003 \\
\hline Nature of equipment to be installed & 0.566 & 0.690 & -0.046 & -0.048 & -0.015 \\
\hline Level of awareness & 0.677 & 0.169 & 0.035 & 0.292 & 0.247 \\
\hline Level of demand for building commissioning practices & 0.639 & 0.118 & 0.020 & 0.115 & 0.531 \\
\hline $\begin{array}{l}\text { Rate of financial return from the adoption of } \\
\text { building commissioning practices }\end{array}$ & 0.683 & 0.161 & 0.387 & 0.136 & 0.158 \\
\hline Level of technology involved & 0.790 & 0.190 & 0.068 & 0.311 & 0.026 \\
\hline Scope of building materials and applications needed & 0.845 & 0.169 & 0.110 & 0.228 & 0.016 \\
\hline Phases of renovation involved in a building project & 0.904 & 0.093 & 0.127 & 0.175 & -0.043 \\
\hline Scope of HVAC component needed & 0.001 & 0.323 & 0.676 & 0.253 & 0.088 \\
\hline Level of demand for elaborate building systems & 0.302 & 0.151 & 0.231 & 0.651 & 0.121 \\
\hline Level of government support & 0.050 & 0.308 & -0.731 & 0.243 & 0.122 \\
\hline Proficiency of design and construction professionals & 0.161 & -0.073 & 0.715 & 0.128 & 0.139 \\
\hline $\begin{array}{l}\text { Level of sophistication and functional testing during } \\
\text { start-up }\end{array}$ & -0.047 & 0.076 & 0.035 & 0.017 & 0.894 \\
\hline Cost and commissioning and retro-commissioning & 0.337 & 0.473 & 0.222 & 0.479 & 0.084 \\
\hline Fees paid for the team of professionals on the project & 0.264 & -0.100 & -0.174 & 0.764 & -0.053 \\
\hline $\begin{array}{l}\text { Reliability and performance level of the installed building } \\
\text { components }\end{array}$ & -0.034 & 0.851 & 0.035 & 0.115 & 0.200 \\
\hline Use and alternative use of the buildings & 0.451 & 0.207 & 0.426 & 0.241 & 0.314 \\
\hline Environmental risk assessment of building system & 0.214 & 0.159 & 0.323 & 0.454 & 0.500 \\
\hline
\end{tabular}




\begin{tabular}{|l|c|c|c|c|c|}
\hline \multirow{2}{*}{} & \multicolumn{5}{|c|}{ Component } \\
\cline { 2 - 7 } & 1 & 2 & 3 & 4 & 5 \\
\hline Compliance to LEED principles on building project & 0.220 & 0.382 & 0.364 & $\mathbf{0 . 5 9 4}$ & 0.107 \\
\hline Achievement of green building standards on project & $\mathbf{0 . 5 5 8}$ & 0.322 & 0.244 & 0.133 & 0.203 \\
\hline $\begin{array}{l}\text { Extraction Method: Principal Component Analysis } \\
\text { Rotation Method: Varimax with Kaiser Normalization }\end{array}$ \\
\hline Rotation converged in 9 iterations
\end{tabular}

Furthermore, further insight into the factor analysis in Table 8 shows the extent to which each of the factor groups determines or influences the level of awareness and adoption of building commissioning practices. It can be observed from the table that all the factors identified accounted for $70.978 \%$ level of awareness and adoption of building commissioning practices. This implies that the factors were considered important by the users in influencing their level of awareness and adoption of building commissioning practices.

Among the groups, factors under Group 1 (Level of awareness, Level of demand for building commissioning practices, Rate of financial return from the adoption of building commissioning practices, Level of technology involved, Scope of building materials and applications needed, and Phases of renovation involved in a building project) contributed to $21.600 \%$ variation in the level of awareness and adoption of building commissioning practices; factors in Group 2 contributed to $14.576 \%$ variation; Group 3 accounted for $14.432 \%$ variation; Group 4 (Environmental response factors) $10.557 \%$ variation and Group 5 accounted for $9.814 \%$ variation in awareness and adoption level. Hence, from this result, it can be inferred that factors in group one are considered by the respondents to be the most important factors contributing to the adoption of building commissioning. This is followed by factors in group two, three, four and five in descending order of ranking. The information on the total variance on the factors influencing adoption of building commissioning practices is shown at Table 8 .

Table 8. Total Variance on the Factors Influencing Adoption of Building Commissioning Practices (developed by the authors)

\begin{tabular}{|c|c|c|c|c|c|c|c|c|c|}
\hline \multirow{2}{*}{ Component } & \multicolumn{3}{|c|}{ Initial Eigenvalues } & \multicolumn{2}{c|}{$\begin{array}{c}\text { Extraction Sums of } \\
\text { Squared Loadings }\end{array}$} & \multicolumn{3}{|c|}{$\begin{array}{c}\text { Rotation Sums of } \\
\text { Squared Loadings }\end{array}$} \\
\cline { 2 - 11 } & Total & $\begin{array}{c}\% \text { of } \\
\text { Variance }\end{array}$ & $\begin{array}{c}\text { Cumulative } \\
\%\end{array}$ & Total & $\begin{array}{c}\% \text { of } \\
\text { Variance }\end{array}$ & $\begin{array}{c}\text { Cumulative } \\
\%\end{array}$ & Total & $\begin{array}{c}\% \text { of } \\
\text { Variance }\end{array}$ & $\begin{array}{c}\text { Cumulative } \\
\%\end{array}$ \\
\hline 1 & 10.056 & 41.901 & 41.901 & 10.056 & 41.901 & 41.901 & 5.184 & 21.600 & 21.600 \\
\hline 2 & 2.444 & 10.184 & 52.085 & 2.444 & 10.184 & 52.085 & 3.498 & 14.576 & 36.175 \\
\hline 3 & 1.902 & 7.925 & 60.010 & 1.902 & 7.925 & 60.010 & 3.464 & 14.432 & 50.608 \\
\hline 4 & 1.367 & 5.698 & 65.708 & 1.367 & 5.698 & 65.708 & 2.534 & 10.557 & 61.164 \\
\hline 5 & 1.265 & 5.270 & 70.978 & 1.265 & 5.270 & 70.978 & 2.355 & 9.814 & 70.978 \\
\hline
\end{tabular}




\begin{tabular}{|c|c|c|c|c|c|c|c|c|c|}
\hline \multirow{2}{*}{ Component } & \multicolumn{2}{|c|}{ Initial Eigenvalues } & \multicolumn{2}{c|}{$\begin{array}{c}\text { Extraction Sums of } \\
\text { Squared Loadings }\end{array}$} & \multicolumn{2}{c|}{$\begin{array}{c}\text { Rotation Sums of } \\
\text { Squared Loadings }\end{array}$} \\
\cline { 2 - 11 } & Total & $\begin{array}{c}\text { \% of } \\
\text { Variance }\end{array}$ & $\begin{array}{c}\text { Cumulative } \\
\%\end{array}$ & Total & $\begin{array}{c}\text { \% of } \\
\text { Variance }\end{array}$ & $\begin{array}{c}\text { Cumulative } \\
\%\end{array}$ & $\begin{array}{c}\text { Total } \\
\text { \% of }\end{array}$ & $\begin{array}{c}\text { Cumulative } \\
\text { Variance }\end{array}$ \\
\hline 6 & 0.926 & 3.860 & 74.838 & - & - & - & - & - & - \\
\hline 7 & 0.891 & 3.712 & 78.550 & - & - & - & - & - & - \\
\hline 8 & 0.714 & 2.977 & 81.527 & - & - & - & - & - & - \\
\hline 9 & 0.648 & 2.700 & 84.227 & - & - & - & - & - & - \\
\hline 10 & 0.516 & 2.151 & 86.378 & - & - & - & - & - & - \\
\hline 11 & 0.469 & 1.952 & 88.330 & - & - & - & - & - & - \\
\hline 12 & 0.461 & 1.921 & 90.252 & - & - & - & - & - & - \\
\hline 13 & 0.424 & 1.765 & 92.016 & - & - & - & - & - & - \\
\hline 14 & 0.378 & 1.573 & 93.590 & - & - & - & - & - & - \\
\hline 15 & 0.314 & 1.310 & 94.899 & - & - & - & - & - & - \\
\hline 16 & 0.270 & 1.288 & 96.189 & - & - & - & - & - & - \\
\hline 17 & 0.222 & 1.118 & 97.305 & - & - & - & - & - & - \\
\hline 18 & 0.172 & 1.100 & 98.405 & - & - & - & - & - & - \\
\hline 19 & 0.136 & 0.921 & 99.326 & - & - & - & - & - & - \\
\hline Extraction Method: Principal Component Analysis. & & - & - & - & - \\
\hline
\end{tabular}

The summary of findings can be found in the next section.

\section{SUMMARY OF FINDINGS}

This section gives summary of the findings of this study. It was obtained from the study that a majority of the respondents had bachelor's degree and had 5-10 years of working experience in the construction industry with engagement in about 5-10 building projects. From past studies in relevant built environment studies, a mean score of 3.0 was noted to be significant in the assessment of the issue under investigation. Similarly, in this study, on the characteristics of building commissioning practices, the respondents were involved in lighting, heating, ventilation and air conditioning, and vertical transporting system with a mean score value of 4.45, 4.15 and 3.82, respectively. An appreciable size of the professionals, the respondents involved in building projects execution, understood building commissioning practices and their awareness was through different media such as professional practices, academic/professional workshops and secondary-related sources. The chi-square analysis indicated that there was a significant relationship between the awareness of the respondents and the adoption of building 
commissioning practices at $95 \%$ confidence level. Factor analysis was carried out on the factors influencing the choice of building commissioning practices, while the associated factor loading and component matrix of the grouped factors were equally indicated.

\section{CONCLUSION}

The study investigated the adoption of building commissioning practices in the installation and use of building services system with a view to assessing the level of awareness of their adoption in Lagos State, Nigeria. It found that the respondents had awareness of the characteristics and functions of building commissioning practices through various professional and academic programmes they were involved in. They participated in various building projects, involving lighting, heating, ventilation, air conditioning and vertical transporting systems that required commissioning practices and different factors were found to be responsible for their adoption. In order to entrench the benefits associated with the adoption of building commissioning practices in the installation and use of service items, it was recommended that the level of awareness should be increased at different workshops and seminars so that professionals in the construction industry can be kept more informed on their applications and relevance. There is a need to have provisions in the National Building Code of the Federal Republic of Nigeria being revised to accommodate the need for building commissioning practices/initiative to be integrated into the frame of building projects delivery so as to improve performance of building stock as practiced in countries such as the United States that allow commissioning be part of their LEED requirements of the Green Building Council (USGBC). Building commissioning should be integrated into the curriculum of built environment studies in higher institutions of learning so as to promote awareness during the training of future construction professionals.

\section{REFERENCES}

Altwies, J. (2002). Commissioning for LEED. Proceedings, Third National Conference on Building Commissioning, PECI, Milwaukee, USA.

ASHRAE (2005). The Commissioning Process: ASHRAE Guideline 0-2005. American Society of Heating, Refrigerating, and Air Conditioning Engineers, Inc.

Asiamah, N., Mensah, H. K. and Oteng-Abaye, E. F. (2017). General Target and Accessible Population: Demystifying the Concept for Effective Sampling, The Qualitative Report, 22(6), 1607-1622.

Bourdeau, L. (1999). Sustainable Development and the Future of Construction: A Comparisons of Visions from Various Countries, Building Research and Information, 27(6), 354-366. https://doi.org/10.1080/096132199369183

D'Antonio, P. (2007). Cost and Benefits of Commissioning LEED-NC Buildings. Proceedings, 15th National Conference on Building Commissioning, PECI, Chicago, USA.

DOE. (2007). DOE Energy Star Building Manual: Re-commissioning Guide. U.S. Department of Energy. Retrieved December 28th, 2008.

Dorsett, R. (2008). Building Commissioning from Contractor's Perspective. A Thesis in M.Sc. in Building Construction Submitted to the Graduate School of the University of Florida.

Energy Design Resources. (2005). Building Commissioning Guidelines. Retrieved December 28th, 2008, from http://www.energydesignresources.com/docs/ch-complete.pdf 
Engineered Systems. (2005). Successful Building Commissioning requires special skills and experience - the TABB Commissioning Certification Program is announced for Spring 2005. Retrieved December 28th, 2008, from http://findarticles.com/p/articles/mi_m0BPR/is_5_22/ai_n13773669

EPA. (2001). Appendix B: Commissioning Guidelines. U.S. Environment Protection Agency. Facilities Manual, Volume 2. Retrieved December 29th, 2008, from http://www.epa.gov/greeningepa/documents/ae-guidelines_appendixb.pdf

Evans, M. (2011). Building Commissioning: A Golden Opportunity for Reducing the United States Emissions, Energy Efficiency, 4(2), 145-173. https://doi.org/10.1007/s12053-011-9116-8

Federation of Construction Industry (FOCI). Information on Construction Firms. Retrieved from https://foci.org.ng/

Johnson, K. (2018). Commissioning, Energy Management. What are the Different Types of Building Commissioning. Retrieved from www.kw-engineering.com/different-types-buildingcommissioning

Judelson, J. (2007). LEED-ing the Way. United States Green Building Council. United States Green Building Council. Accessed January 12th, 2008. Retrieved from http://www.usgbc.org/News/PressReleaseDetails.aspx?ID=3421

Kaiser, H. (1974). An Index of Factor Simplicity, Psychometrika, 39(1), 31-36. https://doi.org/10.1007/BF02291575

Kenneth, N. R. (2005). Sample Design for Educational Research, International Institute for Educational Planning/UNESCO, Module 3.

Korb, K. A. (2012). Conducting Educational Research: Identify the Population, Accessed January 21st, 2019. Retrieved from http://www.korbedpsych.com/Ro5Population.htm

Levy, P. S. and Lemeshow, S. (2009). Sampling of Populations: Methods and Applications, 4th Edition, Wiley, UK.

Mantai, M. (2006). Expanded Role of the Commissioning Provider for LEED Projects. Proceedings, 16th National Conference on Building Commissioning, PECI, San Francisco, USA.

Maisley, G. and Milestone, B. (2006). Total Quality Commissioning: A Performance Based Approach to Commissioning Mechanical Systems. Proceedings, 1st Annual Building Commissioning Association's Tools and Technology Expo, BCA, Austin, USA.

Mills, E. (2011). Building Commissioning: A Golden Opportunity for Reducing Energy Costs and Greenhouse Gas Emissions in the United States. Energy Efficiency, 4(2), 145-173. https://doi.org/10.1007/s12053-011-9116-8

National Environmental Balancing Bureau (2019). NEBB/ANSI Standard 110 Whole Balancing Technical Commissioning of New Construction, Building Systems Commissioning Seminar.

National Institute of Building Sciences (2016). WBDG Project Management Committee, NIS, Innovative Solutions for the Built Environment, Owner's Role and Responsibilities in the Commissioning Process, Updated, 11-15.

Peter, T. (2015). Commissioning: A Primer, DLR Group. Retrieved from www.dlrgroup.com/media/articles

Raymond, A. D. (2010). Budgeting for Commissioning, Total Building Commissioning, 4 June. Retrieved from www.totalbuildingcommissioning.com

Sarmah, H. K. and Hazarika, B. B. (2012). Importance of the Size of Sample and its Determination in the Context of Data Related to the Schools of Guwahati, Retrieved April 2nd, 2019, from www.researchgate.net/publication/306099484

Schreuder, H. T., Ernst, R. and Ramirez-Maldonado, H. (2004). Statistical Techniques for Sampling and Monitoring Natural Resources, General Technical Report, USDA, RMRS-GTR-126, Rocky Mountain Research Station.

Shoop, J. (2005). Steps to Commissioning Success: Commissioning Authority Certification Helps Owners Get What They Pay For. HPAC Engineering. December 2005. Retrieved December 28, 2007, from http://www.hpac.com/Issue/Article/24428/24428

Turkaslan-Bulbul, M. (2006). Process and Product Modeling for Computational Support of Building Commissioning. Retrieved December 12, 2007, from http://www.sciencedirect.com/science

Tseng, P. (2005). Building for the Future: A Supplement to Commissioning Sustainable Buildings for ASHRAE, 2, 17-19. 


\section{AUTHORS' SHORT BIOGRAPHIES}

Akeem Bolaji Wahab is a Senior Lecturer at the Department of Building, Obafemi Awolowo University, Ile-Ife, Nigeria. Dr. Wahab graduated from the Department of Building, Obafemi Awolowo University, Ile-Ife in 1998 with a Bachelor of Science Degree (Second Class Upper Division). He obtained M.Sc. Degree in Environmental Control and Management and Building Services in 2003 and 2011, respectively from the Obafemi Awolowo University, Ile-Ife and also obtained Ph.D. Degree in Building Services from the Obafemi Awolowo University, Ile-Ife in 2016. The main thrust of his research has been on environmental sustainability of building stock, building management system and also on the use of services items in buildings so as to improve comfort drive of the building occupants both indoor and outdoor. He has professional and administrative experiences in built environment practice and has brought these to bear in his teaching and services to the Department, Faculty, University and Community at large. He has served as a reviewer to journals within and outside Nigeria. He has held many posts such as the Vice Chairman, The Nigerian Institute of Building (NIOB), Oyo State Chapter (2016 - to-date), Members/Chairmen of various steering committees set up by the Institute in Oyo State, Nigeria. He has been serving as an invited resource person in many programmes, such as Doing Business in Nigeria Project, facilitated by the World Bank amongst others. He has also held positions like the Assistant General Secretary (2010-2012), General Secretary (2012-2014) and Treasurer (2014-2016) of the Oyo State Branch of the Association of Professional Bodies of Nigeria (APBN).

Kingsley Omaka is a graduate of the Department of Building, Obafemi Awolowo University, Ile-Ife, Nigeria. He has been actively involved in the design, planning, construction and maintenance of building projects with due recourse to sustainability principles. He is currently involved in the production management of building projects handled by the Lagos State Ministry of Works and Housing. Amongst building sites where he has been involved are at the Banana Island, Ikoyi, Lagos, Nigeria. His core research focuses are in the areas of facility management and building management system. He is also into the area of building informatics. He is a Graduate Member of the Nigerian Institute of Building (NIOB). 